\title{
Academic Staff Competence Development as a Gap in Quality Assurance in Universities in Uganda
}

\author{
Peter Neema-Abooki ${ }^{1}$ \\ ${ }^{1}$ Makerere University [* E-mail: pnabooki@yahoo.co.uk]
}

\begin{abstract}
Over the last three decades, higher education institutions (HEIs) in Uganda have accepted an unprecedentedly high number of students. However, as this trend has improved access and equity, it has also affected aspects of quality assurance in higher education delivery. Subsequently, attention is being paid to development of structures for quality assurance. However, despite commonplace understanding that quality in university education depends on the quality of the academic staff, universities are paying little attention to the professional competence of the latter. This paper discusses this anomaly with the conclusion that it threatens quality, especially in today's digital era. Therefore, "analysis of quality in every single task" (QUEST) approaches are recommended for the universities.
\end{abstract}

Keywords: Quality assurance; Competence development; Academic staff.

\section{$1 \quad$ Introduction}

Universities in Uganda have over the last two decades experienced an upsurge of student numbers and programmes amidst scarce resources. Such a predicament of massification, according to Rüland (2013), can be seen as an opportunity and as a tremendous challenge. The quoted scholar envisions it an opportunity since this stance will allow higher education to feature more prominently in education policy-making. It is, on the other hand, a challenge because it remains unclear as to where qualified lecturers can be found to teach these students. In the ambit of the foregoing "challenge", a survey on strategies to increase $\mathrm{PhD}$ production in African universities by Lee (2013) registered "setting high expectations and clear guidelines for performance" as priorities by the institutions. The said survey was conducted at the universities of Cape Town, Pretoria, Rhodes and the Western Cape (all in South Africa); the 
Universities of Ibadan and Obafemi Awolowo in Nigeria (all in West Africa), the University of Nairobi in Kenya and Makerere University in Uganda (all in East Africa).

Anecdotally, much emphasis is put on adequacy of the physical facilities needed by the university, academic programmes, library services, administrative structure and staff/student ratio, among other things. Little or no attention is put on the professional competence of the teaching staff that serve in these universities. This leaves one to doubt the quality of teaching and research provided thus questioning the quality of graduates these universities produce (Kasule and Neema-Abooki, 2009). It is imperative to add heretofore that the uncertainty on the quality of teaching and research is in amity with the doubt on the competencies related to open learning, and the relationships between informal learning and credentialing.

Moreover, the perennial call of the National Council for Higher Education (NCHE) is that every university educator must be given the opportunity to improve academically. Suffice to state that the NCHE was established for regulating and guiding the establishment and management of institutions of higher learning, regulating the quality of higher education, equating of qualifications, and advising government on higher education issues (Kasozi, 2006). The NCHE recognize that knowledge and wisdom are acquired through observation, research and learning, it also requires each institution to inform annually of the mechanisms it has put in place for staff development and the number of beneficiaries in each discipline/ programme.

Nevertheless, universities have always been concerned with systems of quality improvement as regards, among others, teaching and learning. To this effect, Adegbasen (2011) calls for deliberate, evidence-based strategies and processes of satisfying quality norms and criteria from the point of view of processes, environment and product. According to him "quality control" is one of the strategies establishing quality assurance $(Q A)$. Meanwhile QA is perceived not only as a combination of planned and systematic activities implemented in an education system so as to fulfil quality requirement for education in line with acceptable standard (Sanga, 2012; Kihwelo, 2013), but also as a systematic measurement associated with feedback loop that confer error prevention (Kihwelo, 2013).

Accordingly, this paper regards QA in higher education as a systematic process of assessing and verifying inputs, outputs and outcomes against standardized benchmarks of quality so as to maintain and enhance quality, ensure greater accountability and facilitate harmonization of standards across academic programmes, institutions and systems (UNESCO, June 2013). Moreover, in the perception of van Brank (2014), a QA strategy should generally include two basic areas; namely: how to address errors (quality related events), and how to improve practice before an error occurs (continuous 
quality improvement). Within the same perspective, Makerere University SelfAssessment Report (2013) states that the purpose of the quality assurance policy should be to enhance the effectiveness of the University's activities focusing on its contribution to and alignment with the University's Strategic Goals and to match with the international standards against verifiable processes and outcomes. Equidistantly, the Report subscribes that effectiveness and clarity of standards are measures of quality of an institution.

In consonance, Cheng (2013) views education quality as the character of an input, process and output of the education system that satisfy both internal and external stakeholders by meeting their explicit and implicit expectation. Adegbesan (2011) defines quality of education as the various components of face-to-face teaching like the infrastructure and basic amenities, social and geographical environmental professional competence of the teaching, administrative and finance, staff, appropriateness and relevance of the curriculum, teaching-learning materials, teaching, and learning processes, community support to the institution, performance evaluation of the teacher, students, and system that are looked at as a whole. Without prejudice to the foregoing Shahid and Wahab (2015) single out curriculum design, quality of the faculty, quality of research, available technological infrastructure, administrative policies, and accreditation regime as the key factors that influence the quality of higher education. While Jarvis (2014) holds that higher education providers bear a responsibility of assuring quality and quality assurance in order to establish and sustain effective institutional QA systems and processes which yield reliable information for internal planning and improvement of external audit, Yirdaw (2016) is categorical that quality education is considered as one of the major elements that guarantee sustainable economic and social development at the national and regional levels of a given economy.

Meanwhile, quality is defined by van der Bank (2014), as absolute (given and considered as a highest standard), relative concept (quality can be measured in terms of certain specifications), process (for service to achieve quality, certain processes have to conform to procedural requirements), and a culture (recognizes the importance of an organizational view of quality as a process of transformation). More still, the celebrated author states that various definitions of quality are classified into five categories in Higher Education, namely: exceptional, perception or consistency, fitness for purpose, value for money, and transformation. As for Kihwelo (2013), the term "quality" is an amalgam of two concepts. The first is the essential character with which something is identified or described. The second is in reference to the superiority or rank of a particular merchandise.

Suffice to emphasize that trained and skilled human resource is one of the most critical economic requirements confronting institutions of higher learning 
in developing countries like Uganda. For, university education is expected to produce the highest level of human resources of the country and to ensure continuation of research programmes and flow of ideas for economic and social development (Kasule and Neema-Abooki, 2009). Anecdotally, most universities are understaffed, and even the available full-time academic staff spends most of the time moonlighting in several other institutions. This divided-loyalty of service impacts negatively on the delivery of quality education and commitment to the realization of the university's Vision and Mission.

Whereas the vision is futuristic, the mission defines what ought to be done here and now. While Shahzad, Zia, Aslam, Syed and Bajwa (2013) qualify both vision and mission to be the starting point for strategy formulation. David, David and David (2014) - besides subscribing that the former provides strategic direction to the organisation - do conceive complementarity on the twin-terms; holding that both vision and mission do inherently emphasize customer orientation and excellence and at once do initiate and sustain competition which is a key underpinning for quality. Mooney (2013) summarizes that society has strived for quality since ancient human civilization.

Since quality has become a matter of major importance for higher education institutions generally (Inglis, 2005), quality of university education is increasingly becoming a subject of concern. The job market is getting tighter and even a degree from a reputable university no longer guarantees employment despite the graduate's expertise in a given area. Students, their families, employers, and the government want assurance that the students will get good and quality education. For, what will render an iota of fulfilment to students themselves as well as their parents and / or guardians is the knowledge and competence in "job-creating", rather than in job-seeking" (Kasule and Neema-Abooki, 2009).

This paper calls higher education systems to borrow strategies from organisations which operate under the most competitive environment. A case in point is the business sector that has embraced the concept of competence development of employees. Such a concept ought to be regarded as incumbent even upon the academic staff in universities.

Competence development means an individual's competence and proficiency development throughout the working career. In one's own work, competence development can refer to updating, expanding, deepening or completely redirecting one's potential. The objective of competence development is the comprehensive development of the work community and organisation. Competence development is part of the strategic operations planning of an organisation, and the direction and objectives of the development stem from the strategic objectives of the organization. The significance and importance of 
competence development must be recognised and acknowledged throughout the organisation, top management included (Economit, nd).

The competence movement is spreading across different sectors of management but anecdotal evidence reveals that little or nothing has been done to extend the motion in the education sector, especially in the Sub Saharan African region. It is therefore paramount to explore ways of integrating competence-based education in training institutions. Without indulging into such a treatise, this paper suffices to highlight with Everhart (2014) that the structure for competency based learning comes from creating, managing, and aligning sets of competencies to learning resources, assessments, and rubrics, with analytics to track performance. Focusing on outcomes empowers faculty and academic leaders to:

1. Develop robust sets of learning outcomes and competencies

2. Reorient curricular design to start with learning outcomes rather than starting with time/term structures

3. Build high-quality sharable resources, assessments, and rubrics designed to support learning outcomes

4. Foster authentic assessment that includes demonstrated mastery of competencies

5. Effectively identify risk in students' progress toward learning achievements and provide appropriate interventions

6. Support transparent analysis of learning outcomes at every level of the institution

7. Achieve short-term and long-term academic performance improvements focused on outcomes rather than inputs (Everhart, 2014).

The paper heretofore calls institutions of high learning in Uganda to give attention to the foregoing, among others, if quality and competence are to be maintained as sine qua non tenets for development and sustainability.

\section{Ugandan Higher Education in a Digital Age}

In pre-colonial Africa, University education was considered a public good and therefore was exclusively provided for by the Government. Today majority of the governments in developing countries are under great pressure to restrain public spending on higher education. The structural adjustment programs favoured by the IMF and World Bank emphasize reduction in public expenditure, largely because of budget deficits and external debts. This state of affairs has prompted many countries to search for alternative sources in the 
provision of Higher Education other than the public treasury" (Kishore, 2008, cited in Rabwoni, 2010).

At the time of Independence, Uganda inherited and continued with the colonial approach to university education. Karen (2008), as quoted in Rabwoni (2010), argues that the students then acquired quality education that was facilitated by the suitable learning environment, well trained and committed personnel, sufficient learning materials, reasonable student teacher ratio and general stability in the country. For decades, Makerere University which was the only university in Uganda enrolled fewer than three thousand students, all on full government scholarships. This trend changed in 1992 when for the first time government liberalized the education system thereby making a major shift from the decade's old colonial approach. Ten times the usual number of students was admitted, with only a small percentage being government sponsored (Rabwoni, 2010).

Askance with the foregoing, a craze of private universities is currently the order of the day in Uganda. Yet, anecdotal evidence has somewhat portrayed that the increase in the demand for university education and the mushrooming of private university-level institutions has raised eyebrows in regard to quality issues.

In a bid to safeguard the public good, and to secure the future of higher education, public universities in Uganda, according to Rabwoni (2010), have embarked on partnerships with the private sector. The collaboration of the two bodies has seen the thriving of the academic world. Moreover, in the last several years the interpretation of stakeholder involvement has changed as programmes have focused not just on individual institutions, but the broader communities and the society. In respect to the fore going argument Makerere University has established a linkage with the community through the Makerere University Private Sector Forum (MUPSF).

The foregoing author elucidates that the Forum is regarded as a new vehicle for promoting value addition to the University products in addressing the needs of the private sector. As a central 'hub' for practical support and information dissemination, it encourages and facilitates the University by linking it up with the private sector in socio-economic development, and by initiating demand driven joint research and practice to influence development policy and curriculum review, technology innovations, and projects at national and regional levels.

Waruru (2013) heightens that universities must end the blame game and start engaging the business sector to explore areas of cooperation and establish viable linkages that could result in both parties gaining from a symbiotic relationship. He further subscribes that universities could benefit from joint research with the private sector, which gesture could in turn help institutions fine-tune curricula to meet job market requirements. This scholar calls the 
private sector to award consultancies to universities and urges the latter to share research findings with the private sector and to establish an industrial relations department within their structures.

Talking about enhancement of research, Rüland (2013) observes that quality higher education can only emerge when the research dimension in universities is improved. Aarts and Greijn (2010) agitate for embedding higher education and research within international knowledge networks, while catering for local needs. In this digital age, higher education in Uganda therefore ought to more and more imbibe in the need of organizing education in such a way that learning globally contributes to the capacity to address needs locally. The coauthors subscribe that the importance of international collaboration in higher education and research should always be seen at play. According to Rüland (2013), after years of neglect, the importance of higher education and research for societal development has been rediscovered in Africa. Uganda would not afford to be an exception to this truism. The quoted scholar goes on to observe that underfunding has however left many African universities with inadequate infrastructure and some of their best talent working overseas. Furthermore, the ageing academic staff structure is posing considerable challenges in many places. Simultaneously, due to demographic developments and improvements in schooling, the demand for quality higher education provision is exploding. This has led to a situation where institutions such as the University of Ghana and Makerere University have $90 \%$ of student enrolment at the undergraduate level (Ruland, 2013).

The paper therefore, perceiving that the phenomenon of best-talent-workingoverseas has aggravated brain drain in Uganda, reiterates with Rüland (2013) that the pressure on universities resulting from massification is incessantly on the increase. And of course, this is per se a presupposition to the dire need for academic quality and competence development.

In a move to facilitate towards access to higher education, major reforms are looming for student loan schemes in East Africa as governments seek to raise enrolments and ease the fees burden on parents. According to Nganga (2013), Uganda is in the process of setting up a loan fund for students. If passed, the bill will oblige loan beneficiaries to start repaying a year after completing their courses - even if they do not get a job. Beneficiaries will reportedly have to work for the government until their student loan is fully repaid. While the Finance Minister, has said that Uganda will charge minimal interest on the loans, details are yet to emerge. Kenya charges $4 \%$ interest on student loans. Revealed so far is that once approved, student loans in Uganda will be paid directly to universities to cover tuition fee expenses for students. With the US\$1.9 million seed capital, Uganda hopes to initially cater for at least 1,000 students (Nganga, 2013). 
In an equidistant stance, Distance and Open Learning Programmes are being offered, and even Case Studies have been advanced on Distance and Open Learning Education in African countries including Uganda. For instance at Makerere - the premier University in Uganda - is a School of Distance and Life-Long Learning (SoDLL) whose one of the two Departments is the Department of Open and Distance Learning (DODL). Kigotho (2013) quips that while Makerere University is running several external degree programmes in education, business, and sciences from its School of Distance and Lifelong Learning, Kampala International University, a private institution, has established one of the largest open and distance learning programmes in East Africa. Its College of Education, Open, Distance and e-Learning has crafted more than 20 undergraduate and postgraduate degrees and diplomas that are taught through printed media modules and limited e-learning.. The increasing demand for access to higher education in East African countries has therefore opened opportunities for universities to develop robust distance education programmes, In Kenya, although Kenyatta and Nairobi Universities are ahead of other local universities in distance education, several others - including Moi, Mount Kenya and Maseno - also have advanced distance education programmes. Meanwhile, the Open University of Tanzania (OUT) has established learning nodes in Kenya at Egerton University in Nakuru and KCA University in Nairobi. OUT has started learning operations at Kibungo in Rwanda and plans are under way to open study sites in Burundi and Uganda Accordingly, open and distance learning - owing to its flexibility - has great potential as an effective tool for provision of education in developing countries like Uganda.

This paper resonates with the mind of Rüland (2013) that universities should more and more be enabled to become 'engines of development'. This model sees the university as one of the core institutions in national development. And, in the same words of Cloete, Maassen and Moja (2013), the underlying assumption is that "the university is the only institution in society that can provide an adequate foundation for the complexities of the emerging knowledge economy". The status quo will engender Ugandan higher education (HE) to greater heights in the ideal of credentialing. It is therefore imperative to strengthen the more strategic role of academic quality in the environment of educational development for sustainability in the digital age. To this effect, research on open education, open education practices, and open education resources should be advanced. A further study on Credentialing in Ugandan Higher Education Institutions would provide an overview of the credentialing system and practices including the state of play of policies related to the recognition of prior learning in Ugandan Universities. 
Competence assessment, in terms of learning and teaching, is a fundamental stance that no university should overlook. According to Makerere University Self-Assessment Report (2013), there should as well be self-assessment conducted in order to measure the performance of the University in its core functions of Teaching and Learning, Research and Knowledge Transfer Partnerships. Imperative to highlight, Makerere University in particular based its personal assessment on national, regional and international benchmark metrics. Regarding the international perspective, the University incorporated performance indicators from the Organisation of Economic Corporation for Development (OECD) as published in European Universities Association Quality Assurance: A Reference System for Indicators and Evaluation Procedures.

The foregoing notwithstanding, this paper holds that in as much as it is important to borrow from elsewhere whatever is good and beneficial, a notion whatsoever becomes ideal and fruitful depending on the extent to which it is rendered relevant to the local situation. This is de facto a call to the Ugandan Universities to equate their processes of teaching and learning to the needs of the local environ. Implied also is that academic staff must adequately pass on both practical and theoretical competence to students in the various fields of work. They ought to continuously keep abreast with the teaching, learning and research demands in a university (Kasule and Neema-Abooki, 2009), particularly as open learning transforms curriculum design worldwide.

While competence in general refers to attributes, knowledge, skills, abilities, or other characteristics that contribute to successful job performance (Nazri and Barrick, nd). Kasule (2006) outlines four types of competences requisite with teaching and learning in universities. These are: Technical Competence, Knowledge competence, Professional Competency, Functional Competence, Behavioural, and Ethical.

Without prejudice to the need to define and explicate on each of the foregoing, this paper singles out and construes that Ethical Competence as it were envelops all professional competencies since while ethics studies human conduct with an advocacy to maximizing the good and minimizing the evil, "the $21^{\text {st }}$ century is governed by a new watchword: interdependence. And as ethical rules of the past acquire a new and urgent prominence in the present, we are challenged as individuals, organisations, and society, to become ethically competent in an interdependent world. Emphasis herewith is laid by the Competence Rule which states that competency requires the ability to properly identify the problem to be addressed, the knowledge and experience to complete the assignment competently, and recognition of, and compliance with, 
laws and regulations that apply to the appraiser or to the assignment (Novotny, 2012).

Ethical competence is therefore closely associated with the concept of emotional competence, which determines how well we handle ourselves and each other. While the latter is a learned capability based on emotional intelligence that results in outstanding performance at work, the former is a learned capability based on ethical intelligence that results in smooth harmonious and peaceful relationships at every level in society. Like emotional competence, ethical competence is difficult to measure but its presence or absence in an individual, organisation, or society, is readily observable (Berghofer, nd.).

The lack of satisfactory level of ethical competence as well as professional competence among some academic staff in universities can be deduced from the fact that some are involved in scandals. Anecdotal evidence postulates unbecoming behaviour from some teaching staff in universities. This has resulted into disgruntlement by the clientele. The unbecoming behaviour range from absenteeism from duty, delay or non-feedback to the students about their course works, subjective assessment, sexual harassment, using abusive language, coming late for lectures, to giving marks to students in exchange for sex or money. Such are constantly cited as rampant in most universities; despite the fact that some lecturers in various universities in the country, and probably elsewhere in the world, go unidentified. This host of behaviour cannot permit quality teaching/learning to take place in a university. Implied heretofore is that employees should have unquestionable character; more so university lecturers who are supposed to be models of the students they teach. Kasule and NeemaAbooki, (2009) underscore herewith that each academic staff should endeavour to prove themselves as a reservoir of knowledge and skills which must be nurtured and developed for the teaching and learning of a nation.

This paper heightens that effectiveness and efficiency in universities, like elsewhere in organisations, presuppose a high sense of duty and responsibility towards the entire populace. It catapults the understanding of Berghofer (n. d.) that "the Ethical Competence Framework" incorporates three dimensions of competence, beginning with the personal and moving through social competence to global competence. By including the last dimension, recognition is given to the new imperative of life in the $21^{\text {st }}$ century; namely, that the ultimate determinant of success for humanity is our ability to create a harmonious sustainable global civilization on a finite planet".

Adjacently Becket and Brookes (2005) perceive that interest in quality of higher education has increased because of the need for greater accountability to accompany the significant increase in the size of the student population and the students' greater expectations. Not only the students but, this paper adds, the entire citizenry and indeed the global society. 


\section{Conclusion}

Issues of quality assurance and quality enhancement have acquired a major focus of attention in all spheres of life, education inclusive. It is important to note that higher education is gaining in importance due to the growing need for knowledge and skills in this globalized and knowledge-based economy. Moreover, in most developing countries, education systems are also changing in response to paradigmatic shifts from command to market systems of economic organisation. In these circumstances, achieving competitiveness will require a level of efficiency and effectiveness that, in turn, require analysis of quality in every single task (QUEST).

\section{References}

Aarts, H., Greijn, H. (2010). Globalisation, knowledge and learning: Developing the capacities of higher education institutes. In D Teferra and $\mathrm{H}$ Greijn (Eds.) Higher Education and Globalisation-Challenges, threats and opportunities for Africa. Pp. p. 9-18. Maastricht: Maastricht University and Boston College.

Adegbesan, S.O. (2011) Establishing quality assurance in Nigerian education system: Implication for education managers. Educational Research and Review. 6 (2), 147-151.

Berghofer, D. (nd.) D. The ethical competence framework. Available at: http://www.ethicalleadership.com/content/Ethical\%20Competence\%20Fram ework\%20Intro.pdf. Retrieved: 30 April 2016.

Cheng, Y.C. (2013). Towards the 3rd wave school leadership. In H. Stevenson $\&$ L. Ball (Eds.) Organizing Public Education. New York: Sage.

Cloete, N., Maassen, P., Moja, T. (2013). Higher education and different notions of development. IIE Networker, spring, p. 22.

David, M. E., David, F. R. (2014). Mission Statement Theory and Practice: A Content Analysis and New Direction. International Journal of Business, Marketing and Decision Sciences, 7 (1), 95-110.

Economit (nd). Deeper proficiency through competence development. Available at: https://www.ekonomit.fi/web/en/competence-development. Retrieved 4 April 2016.

Ellis, R. (2014) Quality Assurance for University Teaching. Great Britain: Open University Press.

Everhart, D. (2014). 3 Key Characteristics of Competency Based Learning. Available at: http://blog.blackboard.com/3-key-characteristics-ofcompetency-based-learning/. Retrieved: 29 April 2016. 
Inglis, I, (2005). Quality Improvement, Quality Assurance, and Benchmarking: Comparing two frameworks for managing quality processes in open and distance learning. International Review in Open and Distributed Learning. 6 (1). Available at: http://www.irrodl.org/index.php/irrodl/article/view/221/304. Retrieved 4 April 2016.

Jarvis, D. S. (2014). Regulating higher education: Quality assurance and neoliberal managerialism in higher education-A critical introduction. Policy and Society, 33 (3), 155-166.

Kasozi, A. B. K. (2006). A proposed quality assurance framework for institutions of higher learning in Uganda. Paper presented at the seminar on Quality Assurance in Tertiary Education. Available: http://siteresources.worldbank.org/education/Resources/uganda_qaframework.pdf. Retrieved 4 April 2016.

Kasule, G. W., Neema-Abooki, P. (2009). Professional Development: The Case of Academic Staff in a Ugandan Public University. In J Holbrook and P. Eniayeju (Eds.). Meeting Challenges to Sustainable Development in Africa through Science and Technology Education. ICASE, Abuja.

Kigotho. W. (2013, 21 July). Demand drives growth of open learning in East Africa. University World News. Available: http://www.universityworldnews.com/article.php?story=2013071917454262 5. Retrieved 4 April 2016.

Kihwelo, P. F. (2013). Quality Assurance System in Open and Distance Learning for Normative Judgment. HURIA, 14 (1), 1-21.

Lee, P. (2013). Survey reveals strategies to increase $\mathrm{PhD}$ production. University Global News. 15 November 2013 Issue No: 296.

Makerere University Self-Assessment Report (2013). Directorate of Quality Assurance: Becoming a Learner Centred Research Led University. Kampala: MPK Graphics Limited.

Mooney, G. (2013). History of Quality Assurance. Boston: Smart Bear technologies.

Neema-Abooki, P. (2009). Policy initiatives on science and technology education in Uganda: Extent of implementation at the post-basic level. In J. Holbrook \& P. Eniayeju (Eds.). Meeting Challenges to Sustainable Development in Africa through Science and Technology Education. Abuja: ICASE.

Nganga, G. (2013). Student loan systems restructured across East Africa. University Global News. Africa Edition. 15 November 2013 Issue No: 296.

Novotny, W. M. 2012). When Value is in Doubt-Find Out. Available: https://novotnyappraisal.com/Competency_Disclosure.html. Retrieved: 30 April 2016. 
Rabwoni, J. (2010). Private Sector Participation and the Quality of Academic Programs in Makerere University. Unpublished MA dissertation. Kampala: Makerere University.

Rüland, D. (2013). Enhancing research through international collaboration. University Global News. Africa Edition. 15 November 2013 Issue No: 296.

Shahid, H., Wahab, Z. (2015). Quality assurance mechanism in higher education institutions - a thematic analysis of experts' perspective. [Online] http://mrjpk.com/wp-content/uploads/Issue\%2010/eng/07-

Quality\%20Assurance\%20Mechanism\%20in\%20Higher\%20Education\%20I nstitutions.pdf. Retrieved 4 April 2016

UNESCO (2013). Education Sector Technical Notes: Quality Assurance in Higher Education. Available: http://unesdoc.unesco.org/images/. Retrieved 4-4-2016.

van der Bank, C.M. (2014) Quality Assurance in Higher Education. A case of the Vaal University of Technology, Journal of Education and Social Research, 4 (1), 395-406.

Waruru, M. (2013). Call for strong links between universities, companies. University Global News. Africa Edition. 15 November 2013 Issue No: 296.

Yirdaw, A. (2016). Quality of Education in Private Higher Institutions in Ethiopia: The Role of Governance. Thousand Oaks: Sage. 